\title{
THE RELATIONSHIP OF THESIS GUIDANCE THROUGH ONLINE MEDIA WITH STRESS LEVEL OF NURSING STUDENTS
}

\author{
Herwinda Sinaga ${ }^{1}$ \\ ${ }^{1}$ Program Studi Keperawatan Stikes Immanuel Bandung \\ Email : bonorsinagaerwin@gmail.com
}

\begin{abstract}
Stress is a body response that is not specific to problems or burdens, feelings of discomfort, or pressure, both physical and psychological as an individual response, online guidance that is felt to lack interaction between lecturers and students can form a learning process. This study aims to see the relationship between thesis guidance through online media and the level of stress of the eighth semester nursing students at the Immanuel College of Health, Bandung. This research is a type of quantitative research that uses a cross sectional approach. The sample in this study may be 42 respondents using total sampling technique. The instrument used was a questionnaire instrument to measure stress levels using DASS 42 and online guidance using a closed questionnaire. The results of the analysis of this study using the Spearman Rank test indicate that there is a relationship between thesis guidance through online media with the stress level of semester VIII nursing students at Immanuel College of Health Sciences Bandung ( $p$-value $0.000<0.05$ ). Suggestions are expected to align online and offline thesis guidance activities carried out by lecturers with the distribution of the proportions, so that it can make it easier for lecturers to evaluate students' understanding of the preparation of final study assignments (Thesis) and can reduce stress that has a negative impact on students.
\end{abstract}

\section{Keywords: Final year student, Online Tutoring, Stress level}

\section{PENDAHULUAN}

Stres merupakan respon tubuh yang bersifat tidak spesifik terhadap tuntutan atau beban,perasaan tidak enak, tidak nyaman, atau tertekan, baik fisik maupun psikis sebagai respon atau reaksi individu (Hans selye dalam Mad Zaini.2019). Stress merupakan kondisi yang tidak menyenangkan dimana manusia melihat adanya tuntutan dalam situasi sebagai beban atau diluar batas kemampuan mereka untuk memenuhi tuntunan tersebut (Nasir \& Muhith,2011). Penyebab timbulnya stress pada mahasiswa menurut Saam (2013) adalah faktor pribadi, faktor keluarga, dan faktor akademik. Faktor pribadi meliputi tidak bisa membagi waktu, faktor keluarga meliputi dukungan

Jurnal Vokasi Keperawatan (JVK) Volume 4 No 1 Bulan Juni Tahun 2021 Program Study of Nursing Universitas Bengkulu http ://ejournal.unib.ac.id/index.php/Jurnal Vokasi Keperawatan 
keluarga dan faktor akademik meliputi tugas yang terlalu banyak atau menumpuk. Sedangkan menurut Indarwati (2018) faktor penyebab yang mempengaruhi munculnya stress pada mahasiswa terdiri atas dua faktor yaitu faktor internal dan eksternal. Faktor internal meliputi kemampuan atau kecerdasan seseorang. Sedangkan faktor eksternal meliputi tuntutan kampus, keluarga dan keuangan.

Pembelajaran online atau e-learning merupakan pengembangan sistem pembelajaran jarak jauh. Secara umum pendidikan jarak jauh didasarkan pada keterpisahan antara siswa dan pengajar, pemanfaatan (paket) bahan belajar yang dirancang secara sistematis (Tian dalam Fina,2010). Begitu juga Bimbingan online adalah proses pemberian bantuan yang diberikan kepada peserta didik dengan menghubungkan pemahaman dan menyusun rencana menggunakan jaringan yang terhubung dalam jaringan, satu perangkat dengan perangkat lainnya sehingga bisa saling berkomunikasi (Dwiyani,2013).

Permasalahan yang dialami saat bimbingan online atau pembelajaran online (Munir dalam Siti,2016) yaitu kurangnya interaksi antara guru dan siswa dapat memperlambat terbentuknya proses pembelajaran, proses pembelajaran memerlukan motivasi yang tinggi karena pembelajarannya dilakukan secara mandiri, dan tidak semua siswa dapat memanfaatkan internet karena terbatasnya fasilitas yang dimiliki, serta kurangnya pengetahuan dan keterampilan (skill and knowledge) dalam mengoperasikan komputer dan memanfaarkan internet secara maksimal.

Hasil studi pendahuluan pada tanggal 21 April 2020 sebagai data awal yang dilakukan di Sekolah tinggi Ilmu kesehatan Immanuel bandung pada mahasiswa S1 semester VIII dengan total jumlah 61 orang dengan 13 orang S1 gizi, 6 orang S1 Kesehatan Masyarakat. Namun sebanyak 10 orang dari jumlah total 42 orang S1 Keperawatan sebagai data awal dengan metode wawancara yang dilakukan melalui aplikasi google form didapatkan hasil 8 dari $10(80 \%)$ mahasiswa yang memilih setuju dengan adanya bimbingan online merasa malas dalam mengerjakan revisi skripsi dan 6 dari 10 (60\%) 
mahasiswa kurang memahami masukan dari dosen pembimbing dan timbulnya rasa cemas dalam proses bimbingan yang belum maksimal dikarenakan metode yang digunakan melalui gmail dan Whatsapp kurang efektif. Dari fenomena diatas, maka peneliti tertarik untuk mengambil judul penelitian tentang "Hubungan Bimbingan Skripsi Melalui Media Online dengan Tingkat Stress Mahasiswa Keperawatan Semester VIII di Sekolah Tinggi Ilmu Kesehatan Immanuel Bandung”.

\section{METODE}

Rancangan penelitian menggunakan penelitian deskriptif kuantitatif, desain yang digunakan adalah desain penelitian deskriptif korelatif dengan pendekatan crosssectional (Nursalam.2016). Bertujuan untuk mengidentifikasi ada atau tidaknya hubungan antara bimbingan skripsi melalui media online dengan tingkat stres mahasiswa keperawatan semester VIII di Sekolah Tinggi Ilmu Kesehatan Immanuel Bandung.

Cara kerja penelitian ini dilakukan dengan menyebarkan kuesioner, kuesioner yang digunakan dalam penelitian ini menggunakan bantuan digital yaitu Google Form. Aplikasi ini digunakan untuk mempermudah dalam menyebarkan kuesioner, yaitu dengan cara menginput pertanyaan kuesioner melalui google form dan nantinya disebarkan secara digital kepada responden penelitian.

Populasi pada penelitian ini adalah semua mahasiswa/i keperawatan semester VIII yang berjumlah 42 orang di Stik Immanuel Bandung. Teknik sampel yang digunakan adalah total sampling, artinya sampel yang digunakan adalah total populasi. Metode ini memperbolehkan karena jumlah populasi yang terbatas atau sedikit, yaitu 42 responden, sampel ini menggunakan kriteria inklusi yaitu mahasiswa yang sedang menyusun skripsi sehingga dari jumlah tersebut dijadikan sampel dalam penelitian. Penggunaan total populasi diharapkan lebih mewakili fakta yang ada (Notoatmodjo, 2012). 


\section{HASIL}

Hasil analisis bimbingan skripsi melalui media online di Sekolah Tinggi Ilmu Kesehatan Immanuel Bandung.

\section{Tabel 1}

Distribusi Frekuensi Responden Menurut Bimbingan Skripsi Melalui Media Online Mahasiswa Keperawatan Semester VIII

\begin{tabular}{lccc}
\hline \multirow{2}{*}{ Kategori } & \multicolumn{3}{c}{ Bimbingan Online } \\
\cline { 2 - 3 } & F & \% \\
\hline Efisien & 13 & $31 \%$ \\
Tidak Efisien & 29 & $69 \%$ \\
& & \\
\hline Total & 42 & 100 \\
\hline
\end{tabular}

Berdasarkan analisis tabel 1 menunjukkan lebih dari sebagian responden termasuk kategori tidak efisien yaitu sebanyak 29 orang dengan presentase $69 \%$.

Tabel 2

Distribusi Frekuensi Responden Menurut Tingkat Stres Mahasiswa Keperawatan Semester VIII

\begin{tabular}{|c|c|c|}
\hline \multirow[t]{2}{*}{ Kategori } & \multicolumn{2}{|c|}{ Tingkat Stres } \\
\hline & $\mathrm{F}$ & $\%$ \\
\hline Normal & 7 & 16,7 \\
\hline Ringan & 19 & 45,2 \\
\hline Sedang & 15 & 35,7 \\
\hline Berat & 1 & 2,4 \\
\hline Sangat Berat & 0 & 0 \\
\hline Total & 42 & 100 \\
\hline
\end{tabular}

Berdasarkan analisis tabel 2 diatas menunjukkan bahwa hampir setengah dari responden yang mengalami tingkat stress ringan yaitu sebanyak 19 orang dengan presentase $45,2 \%$. 


\section{Tabel 3}

Hasil Uji Korelasi antara Bimbingan Skripsi Melalui Media Online Dengan Tingkat Stress Mahasiswa Keperawatan Semester VIII Di Sekolah Tinggi Ilmu Kesehatan Immanuel Bandung.

\begin{tabular}{|c|c|c|c|c|c|c|c|}
\hline Variabel & & & Tingkat & & & & \\
\hline $\begin{array}{l}\text { Bimbingan } \\
\text { online }\end{array}$ & Normal & Ringan & Sedang & Berat & $\begin{array}{c}\text { Sangat } \\
\text { Berat }\end{array}$ & Jumlah & p-value \\
\hline Efisien & $5(11,9 \%)$ & $6(14,3 \%)$ & $1(2,4 \%)$ & $1(2,4 \%)$ & $0(0 \%)$ & $13(31 \%)$ & \\
\hline Tidak efisien & $2(4,8 \%)$ & $13(31 \%)$ & $14(33,3 \%)$ & $0(0 \%)$ & $0(0 \%)$ & $29(69 \%)$ & 0,000 \\
\hline Total & $7(16,7 \%)$ & $19(45,2 \%)$ & $15(35,7 \%)$ & $1(0 \%)$ & $0(0 \%)$ & $42(100 \%)$ & \\
\hline
\end{tabular}

Berdasarkan analisis tabel 3 diatas menunjukkan hasil uji korelasi menggunakan Spearman Rank didapat nilai probabilitas (p-value) $0,000<(\alpha 0,05)$. Hal ini menunjukkan bahwa terdapat hubungan antara hubungan bimbingan skripsi melalui media online dengan tingkat stress mahasiswa keperawatan semester VIII di Sekolah Tinggi Ilmu Kesehatan Immanuel Bandung. Dengan demikian maka dapat disimpulkan bahwa HO ditolak dan HA diterima.

\section{PEMBAHASAN}

a. Analisa Univariat

1. Bimbingan skripsi melalui media online mahasiswa keperawatan semester VIII di Sekolah Tinggi Ilmu Kesehatan Immanuel Bandung

Berdasarkan hasil penelitian ini, peneliti mendapatkan hasil yakni bimbingan skripsi melalui media online mahasiswa keperawatan semester VIII di Sekolah Tinggi Ilmu Kesehatan Immanuel Bandung menunjukkan lebih dari sebagian responden tidak efisien dalam bimbingan online yaitu 69\%, dan hampir setengah dari responden efisien dalam bimbingan online yaitu $31 \%$.

Penelitian ini sejalan dengan penelitian yang dilakukan oleh Adijaya (2018) tentang Persepsi Mahasiswa Dalam Pembelajaran Online ditemukan bahwa 54 mahasiswa di Universitas Esa Unggul menghadapi beberapa masalah untuk berinteraksi, tidak hanya

Jurnal Vokasi Keperawatan (JVK) Volume 4 No 1 Bulan Juni Tahun 2021 Program Study of Nursing Universitas Bengkulu http ://ejournal.unib.ac.id/index.php/Jurnal Vokasi Keperawatan 
dengan mahasiswa lain tetapi juga dengan dosen. Ditunjukkan pada presentase 57,41\% menyatakan ketidak setujuan terhadap pernyataan yang mengatakan interaksi mahasiswa perkuliahan online telah berjalan dengan baik dan 59,26\% menyatakan menyukai merespon secara langsung dibanding melalui online seperti email. Pembelajaran tradisional atau sering disebut pembelajaran konvensional biasanya dilaksanakan dengan sistem tatap muka (face to face learning). Kegiatan ini dilakukan dengan mempertemukan peserta didik dan pendidik dalam waktu dan tempat yang sama untuk melaksakan proses pembelajaran. System pembelajaran ini memiliki ke khas an tersendiri karena interaksi antara peserta didik dan pendidik terjadi secara langsung tanpa ada perantara. ini dianggap lebih humanis dibanding dengan pembelajaran berbantuan media, karena menghadapkan orang. Oleh karena itu, Dian dan Rakhmat (2017) menjelaskan bahwa sistem pembelajaran ini baik untuk mengajarkan pengetahuan berupa sikap dan nilai.

\section{b. Tingkat stress mahasiswa keperawatan semester VIII di Sekolah Tinggi Ilmu Kesehatan Immanuel Bandung di Sekolah Tinggi Ilmu Kesehatan Immanuel Bandung}

Berdasarkan hasil penelitian ini, peneliti menemukan bahwa menunjukkan hampir setengah responden mengalami tingkat stress ringan $(45,2 \%)$, dan sebagian kecil responden mengalami tingkat stress berat $(2,4 \%)$. Penelitian ini sejalan dengan penelitian yang dilakukan oleh Indarwati (2018) pada Gambaran Stres Mahasiswa Tingkat Akhir Dalam Penyusunan Skripsi di Fakultas Kedokteran UIN Makasar diperoleh mahasiswa mengalami gejala fisik dengan tingkat ringan sebanyak $88,9 \%$ orang dengan gejala seperti sesak napas, berkeringat berlebih, detak jantung tidak stabil.

Mahasiswa mengalami gejala psikologis dengan tingkat ringan sebanyak $85,2 \%$ orang dengan gejala seperti cemas, mudah marah karena hal yang sepele, merasa sedih dan tertekan, mudah panik, takut dan gelisah. Kemudian mahasiswa mengalami gejala perilakupun dengan tingkat ringan sebanyak $92,6 \%$ orang dengan gejala seperti merasa sulit untuk bersantai, tidak mampu bersabar jika mengalami penundaan serta kehilangan minat dan inisiatif dalam melakukan sesuatu. Stres juga didefinisikan oleh Sarafino dan 
Smith (2012) sebagai kondisi yang disebabkan adanya interaksi antara individu dengan lingkungan sehingga persepsi jarak antara tuntutan, berasal dari situasi yang bersumber pada sistem biologis, psikologis dan sosial dari seseorang. Adaptasi psikologis merupakan suatu proses penyesuaian secara psikologis akibat adanya stressor, dengan cara memberikan mekanisme pertahanan diri dimana diharapkan mekanisme ini dapat melindungi dan dapat bertahan dari stressor atau serangan yang tidak menyenangkan baik terhadap reaksi berorientasi pada tugas dan reaksi berorientasi dengan ego.

\section{Analisa Bivariat}

Hubungan Bimbingan Skripsi Melalui Media Online Dengan Tingkat Stress Mahasiswa Keperawatan Semester VIII di Sekolah Tinggi Ilmu Kesehatan Immanuel Bandung

Berdasarkan analisis tabel 3 didapatkan bahwa menunjukkan nilai p-value 0,000 lebih kecil dari nilai kebermaknaan 0,05 yang artinya hasil penelitian ini terdapat hubungan antara bimbingan skripsi melalui media online dengan tingkat stress mahasiswa keperawatan semester VIII.

Peneliti ini sejalan dengan penelian yang dilakukan oleh Kusnayat, et al (2020) pada pengaruh teknologi pembelajaran kuliah online di era Covid-19 dan dampaknya terhadap mental mahasiswa di kampus Telkom University dan UIN SGD Bandung menunjukkan 60,5\% mahasiswa siap beradaptasi dengan penggunaan teknologi pembelajaran perkuliahan online tetapi sekitar 59,5\% keberatan atas tugas yang diberikan dosen yang berakibat tingkat stress mahasiswa sekitar 60\%, dan sebanyak 92\% mahasiswa memilih dan lebih suka perkuliahan tatap muka di kelas dibanding perkualiahan online. Sehingga penelitian ini ada hubungan yang erat antara perkuliahan online dengan sikap mental mahasiswa. 


\section{SIMPULAN DAN SARAN}

\section{SIMPULAN}

Lingkungan pembelajaran online merupakan lingkungan yang tercipta akibat rekayasa teknologi telekomunikasi digital. Lingkungan ini bersifat maya atau virtual (cyberspace) sehingga sekat atau batasannya tidak ada sekat fisik yang membatasinya. Lingkungan ini membawa konsekuensi hilangnya interaksi budaya dalam tatap muka pada pembelajaran konvensional.

\section{SARAN}

Diharapkan penelitian selanjutnya melakukan penelitian dengan variabel lainnya terkait model bimbingan skripsi. diharapkan menyelaraskan kegiatan bimbingan skripsi online dan offline yang dilakukan dosen dengan pembagian proporsi, sehingga dapat memudahkan dosen dalam mengevaluasi pemahaman mahasiswa terhadap penyusunan tugas akhir studi (Skripsi) dan dapat mengurangi stres yang berdampak negatif bagi siswa.

\section{DAFTAR RUJUKAN}

Adijaya N, Pudji L. (2018). Persepsi Mahasiswa Dalam Pembelajaran Online: ejournal Wanastra vol 10 No. 2 hal 105-110.

Aini, Nur. (2018). Teori Model Keperawatan. Malang: Universitas Muhammadiyah Malang.

Arikunto,S. (2013). Prosedur Penelitian Suatu Pendekatan Praktik. Edisi Revisi. Jakarta: PT. Rineka Cipta.

Azwar, S. (2013). Metode Penelitian. Yogyakarta: Pustaka Pelajar

Damanik, E.D. (2014). Damanik translation Bahasa Indonesia. Dalam : Psychology Foundation of Australia. Depression Anxiety Stress Scale (DASS). Diakseshttp://www2.psy.unsw.edu.au/dass/Indonesian/Damanik.htm

Dwiyani, Aprillita. (2013). Perancang Sistem Pendukung Bimbingan Online TugasAkhir Mahasiswa Program Studi Teknik Informatika, hal 1-5. Jurnal PalangkaRaya

Febriani, Deni. (2011). Bimbingan dan Konseling. Yogyakarta: Teras 
Gamayanti, Witrin dkk. (2018). Self Disclosure dan Tingkat Stres pada Mahasiswayang sedang Mengerjakan Skripsi. Hal 1-16. Jurnal Ilmiah Psikologi

Nasrullah, Rulli. (2015). Media Sosial Perspektif Komunikasi, Budaya dan Sosioteknologi. Bandung: Simbiosa Rekatama Media

Puspitasari. (2013). Hubungan antara Manajemen Waktu dan Dukungan Sosial dengan Prestasi Akademik Mahasiswa yang Bekerja. EMPATHY Jurnal Fakultas Psikologi

R, Aditya. (2015). Pengaruh Media Sosial Instagram Terhadap Minat Fotografipada Komunitas Fotografi Pekan Baru. Pekanbaru: JomFISIP vol.2

Riyanto. (2013). Aplikasi Metodologi Penelitian Kesehatan. Yogyakarta: Nuha Medika.

Simanihuruk, Lidia., et al. (2019). E-learning: Implementasi, Strategi, dan Inovasinya. Medan: Yayasan Kita Menulis.

Sumantri, Syarif. (2014). Strategi Pembelajaran. Jakarta: Rajawali Pers 